\title{
Frequency and Diversity of Nitrate Reductase Genes among Nitrate-Dissimilating Pseudomonas in the Rhizosphere of Perennial Grasses Grown in Field Conditions
}

\author{
L. Roussel-Delif ${ }^{1}$, S. Tarnawski ${ }^{1}$, J. Hamelin ${ }^{1}$, L. Philippot $^{2}$, M. Aragno ${ }^{1}$ and N. Fromin ${ }^{1}$ \\ (1) Laboratoire de Microbiologie, Université de Neuchâtel, rue Emile Argand 11, 2007 Neuchâtel, Switzerland \\ (2) Institut National de la Recherche Agronomique, Laboratoire de Microbiologie des Sols, UMRA111, Microbiologie des Sols-Géosols, 21055 Dijon Cedex, \\ France
}

Received: 20 October 2003 / Accepted: 19 February 2004 / Online publication: 11 January 2005

\begin{abstract}
A total of 1246 Pseudomonas strains were isolated from the rhizosphere of two perennial grasses (Lolium perenne and Molinia coerulea) with different nitrogen requirements. The plants were grown in their native soil under ambient and elevated atmospheric $\mathrm{CO}_{2}$ content $\left(\mathrm{pCO}_{2}\right)$ at the Swiss FACE (Free Air $\mathrm{CO}_{2}$ Enrichment) facility. Root-, rhizosphere-, and non-rhizospheric soil-associated strains were characterized in terms of their ability to reduce nitrate during an in vitro assay and with respect to the genes encoding the membrane-bound (named NAR) and periplasmic (NAP) nitrate reductases so far described in the genus Pseudomonas. The diversity of corresponding genes was assessed by PCR-RFLP on narG and napA genes, which encode the catalytic subunit of nitrate reductases. The frequency of nitrate-dissimilating strains decreased with root proximity for both plants and was enhanced under elevated $\mathrm{pCO}_{2}$ in the rhizosphere of $L$. perenne. NAR (54\% of strains) as well as NAP (49\%) forms were present in nitrate-reducing strains, $15.5 \%$ of the 439 strains tested harbouring both genes. The relative proportions of narG and napA detected in Pseudomonas strains were different according to root proximity and for both $\mathrm{pCO}_{2}$ treatments: the NAR form was more abundant close to the root surface and for plants grown under elevated $\mathrm{pCO}_{2}$. Putative denitrifiers harbored mainly the membrane-bound (NAR) form of nitrate reductase. Finally, both narG and napA sequences displayed a high level of diversity. Anyway, this diversity was correlated neither with the root proximity nor with the $\mathrm{pCO}_{2}$ treatment.
\end{abstract}

Correspondence to: N. Fromin; E-mail: nathalie.fromin@unine.ch

\section{Introduction}

The dissimilatory reduction of nitrate to nitrite by bacteria can be followed by a reduction of nitrite to either ammonium during nitrate ammonification, or to gaseous nitrogen compounds $\left(\mathrm{NO}, \mathrm{N}_{2} \mathrm{O}\right.$, and $\left.\mathrm{N}_{2}\right)$ during the respiratory denitrification process. Denitrification was described as the main process of nitrate dissimilation in soil environments $[20,53]$. It depends on the presence and availability of electron donors, mostly organic compounds, and of the electron acceptors (nitrogen oxides, oxygen). All these proximate factors could be modified by plant (exudation of organic compounds, nitrate assimilation) as well as by associated microbiota. Several studies demonstrated that plants influence soil-inhabiting nitrate-dissimilating bacterial microbiota $[12,31,44]$. Indeed, nitrate dissimilation should be favored in the rhizosphere, where rhizodeposition provides organic substrates [46]. Several authors showed that heterotrophic bacteria [29] or Pseudomonas isolates $[11,12,16]$ displaying nitrogendissimilating activity were more frequently detected in root-associated habitats than in nonrhizospheric soil. Moreover, the ability to use nitrate as alternative electron acceptor could be a competitive advantage for bacteria in the rhizosphere, where oxygen is limiting because of root and microbial respiration [21]. In contrast, Nijburg and co-workers [37, 38] reported a lower proportion of nitrate-reducing bacterial isolates in the rhizosphere of the aerenchymatous wetland plant Glyceria maxima compared to nonrhizospheric soil, suggesting that the availability of nitrate is also crucial for nitrate dissimilation. Various studies showed that denitrification in soil is also influenced by soil properties and agricultural practices $[9,12,17,40,54]$. 
Among the factors that might influence denitrification in the soil plant systems, the increasing atmospheric $\mathrm{CO}_{2}$ content $\left(\mathrm{pCO}_{2}\right)$, due to increasing fossil fuel burning and land use conversion [56] is of main interest. Elevated $\mathrm{pCO}_{2}$ induces alteration of both rhizodeposition [15] and nitrogen transformations [34, 48, 57]. Activity measurements have shown that both potential and actual denitrification rates were higher in grassland soils under elevated $\mathrm{pCO}_{2}[6,49]$, resulting in increased nitrous oxide emission $[1,28]$.

The complete denitrification pathway is a modular process comprising four sequential enzymatic reductions (involving nitrate, nitrite, nitric oxide, and nitrous oxide reductases) [59]. The dissimilative reduction of nitrate to nitrite is the most commonly occurring step, and the corresponding genes were used as molecular markers for studying the nitrate dissimilating communities [10, 18, $23,24,39,44]$. So far, two metalloenzymes involved in the dissimilatory reduction of nitrate have been described in bacteria: a membrane-bound nitrate reductase (termed NAR), which is expressed under anaerobic conditions, and a periplasmic enzyme (NAP), whose regulation varies in different organisms $[42,47,59]$. NAP was described as being involved in aerobic or anaerobic nitrate dissimilation, in the transition from aerobic to anaerobic metabolism [3, 47], in dissipating the excess of photosynthetic reducing power [36], or finally in nitrate scavenging [45]. Both forms of nitrate reductases can be present simultaneously in a single strain $[3,7,18,24,41]$.

Numerous investigations suggested that bacteria affiliated to the genus Pseudomonas are the predominant culturable denitrifiers in soil [7-9, 20]. Moreover, Marilley and co-workers [33] showed that the proportion of Pseudomonas was enhanced in the rhizosphere of $L$. perenne grown under elevated $\mathrm{pCO}_{2}$. The nitrate-dissimilating Pseudomonas populations (size and composition) are therefore very likely to be altered in the rhizosphere of plants grown under elevated $\mathrm{pCO}_{2}$. The aim of this work was to assess the influence of the plant and elevated $\mathrm{pCO}_{2}$ treatment on the structure of nitratedissimilating Pseudomonas. Two perennial grasses with different nitrogen requirements [55] were used as model plants: the nitrophilic Lolium perenne and the oligonitrophilic Molinia coerulea. Bacteria affiliated to the genus Pseudomonas were previously shown to account for a significant part of the microbiota associated to the rhizosphere of these two plants $[33,52]$. A large collection of nitrate-dissimilating Pseudomonas strains isolated from the root, rhizosphere, and surrounding soil of these plants was characterized regarding their frequency and their nitrate reductase genes. The nature of nitrate reductase(s) (periplasmic versus membrane-bound) and the diversity of the corresponding narG and napA genes were assessed by PCR and restriction fragment length polymorphism.

\section{Methods}

Study Site and Plant Material. Lolium perenne and Molinia coerulea were grown under ambient (360 ppm, noted $\mathrm{C}$ for control) and elevated $\mathrm{pCO}_{2}(600 \mathrm{ppm}$, noted $\mathrm{T}$ for treated) at the FACE (Free Air $\mathrm{CO}_{2}$ Enrichment) facility, Eschikon, Switzerland [26]. The meteorological data during the period of experiment (rainfall, temperature, and radiation) can be found on the Swiss FACE Web site (http://www.fb.ipw.agrl.ethz.ch/FACE.html). The treated plots have been enriched with atmospheric $\mathrm{CO}_{2}$ during daylight between March and December. $L$. perenne $\mathrm{cv}$ Bastion (noted $\mathrm{L}$ ) was grown as a monoculture on three control $(\mathrm{C})$ and three $\mathrm{pCO}_{2}$-treated $(\mathrm{T})$ replicate plots since May 1993. The plants were grown in the local autochthonous fertile, eutric cambisol. Shoots were harvested four times a year. The $\mathrm{C}$ and $\mathrm{T}$ plots received $14 \mathrm{~g}$ $\mathrm{m}^{-2} \mathrm{y}^{-1} \mathrm{~N}, \mathrm{NH}_{4} \mathrm{NO}_{3}$, (at the beginning of the season, and then after each cut, except for the last). This amount is limiting for plant growth [14]. M. coerulea plants (noted M) originated from a littoral meadow located at the southern shore of Lake Neuchâtel (Cudrefin, Switzerland). The local soil is a gleysol, typic haplaquoll, contained $4.7 \%$ clay, $9.5 \%$ silt, $85.8 \%$ sand, and had a $\mathrm{pH}_{[\mathrm{H} 2 \mathrm{O}]}$ value of 8.4 [25]. Plants with undisturbed root systems were taken with their surrounding and underlying soil and transferred to the FACE facility in September 1999. About $0.7 \mathrm{~m}^{2}$ of littoral meadow with reconstructed soil profile below the root horizon (total depth: $35 \mathrm{~cm}$ ) was installed in one control plot $(\mathrm{C})$ and one $\mathrm{pCO}_{2}$-treated plot $(\mathrm{T})$. M. coerulea plants were neither cut nor fertilized.

Sampling Plan. For L. perenne, the three replicates for both LC and LT plots were sampled in June, July, and October 2000, as well as in July and December of the following year. During the growth season, sampling of $L$. perenne was always performed immediately prior to a cut. For M. coerulea, both $\mathrm{C}$ and $\mathrm{T}$ plots were sampled in June 2000, then in July and December 2001. For each sampled plot, three soil cores ( $\sim 5 \mathrm{~cm}$ diameter, $10-12 \mathrm{~cm}$ depth), including dense root systems, were taken and mixed for analysis. For L. perenne, three fractions were recovered: nonrhizospheric soil (NRS) for soil devoid of roots, rhizospheric soil (RS) for root-adhering soil (recovered by washing the roots twice in $20 \mathrm{~mL}, 0.1 \mathrm{M}$ sodium phosphate buffer, pH 7.0 (SPB), under agitation for $30 \mathrm{~min}$ ), and rhizoplane-endorhizosphere (RE) for thoroughly washed roots. For M. coerulea, the rhizosphere fraction is not easy to define. Thus only two fractions (NRS and RE) were analyzed.

Pseudomonas Isolation. Isolation of Pseudomonas strains was performed as previously described [52]. Briefly, $1 \mathrm{~g}$ of fresh weight root or soil was crushed in 10 
$\mathrm{mL} \mathrm{SPB}$. The root and soil suspensions were 10-fold serially diluted in SPB and spread on $\mathrm{mS} 1$ medium, which is selective for Pseudomonas [19, 52]. Colonyforming units ( $\mathrm{cfu}$ ) were determined after $72 \mathrm{~h}$ of incubation at $24^{\circ} \mathrm{C}$. Twenty (June 2000), 12 (July, October 2000 and July 2001), and 15 bacterial colonies (December 2001) were randomly picked from appropriate dilution plates (between 20 and 200 colonies per Petri dish) and checked for purity on 10-fold diluted Tryptic Soy Agar (Difco). The affiliation of $\mathrm{mS1}$ isolates to the genus Pseudomonas was checked by hybridization with $\mathrm{PSM}_{\mathrm{G}}$ probe [5] and confirmed by PCR amplification of 16S$23 \mathrm{~S}$ rDNA spacer region with Pseudomonas-specific primers [30].

\section{Nitrate Reduction and Denitrification Activity As-} says. Nitrate-dissimilative activities were tested as follows. Each strain was cultivated in duplicate tubes containing $6 \mathrm{~mL}$ Nutrient Broth (devoid of fermentable substrate) (Merck) supplemented with $2 \mathrm{~g} \mathrm{~L}^{-1} \mathrm{KNO}_{3}$. A small inverted Durham tube was added to each tube in order to detect gas formation. The cultures were incubated for 7 days at $24^{\circ} \mathrm{C}$. The presence of nitrate and nitrite in tubes after incubation was evaluated using standard Griess reagent A (sulfanilic acid $0.8 \% \mathrm{w} / \mathrm{v}$ ), reagent $\mathrm{B}$ ( $\mathrm{N}, \mathrm{N}$-dimethyl-1-naphthylamine, $0.6 \% \mathrm{v} / \mathrm{v})$ and powdered zinc to reduce the remaining nitrate to nitrite. If nitrate was not reduced and no gas formation was observed, the bacteria were scored as non-dissimilative (NDi). Strains that were able to reduce nitrate were scored as dissimilative, which included nitrate reducers (NR) and putative denitrifiers (D) [32]. Isolates were scored as NR when no more nitrate was detected and nitrite accumulated in the medium. They were recorded as $\mathrm{D}$ when no more nitrate was detected and gas accumulated in the inverted tube. In this study, the term "denitrifiers" refers to all bacteria that produced gas under the experimental conditions used. The exact gas composition was not determined. In case nitrate removal occurred but neither nitrite nor gas was formed, the bacteria were considered as nitrate ammonifiers or nitrate assimilators. As very few strains did fall in these categories (seven for $L$. perenne and one for $M$. coerulea), the corresponding proportions were not further considered.

The proportions of NR and D Pseudomonas in the different treatments were analyzed using either Tukey multiple comparison test (proportions of NR for Lolium) or Fisher LSD exact test (D proportions for Lolium, NR and D proportions for Molinia). The whole data for $L$. perenne were also analysed using a generalized linear model with a logistic regression model, which is adapted for binary data. This analysis was used to compute the probabilities corresponding to the effects of the parameters (sampling date, $\mathrm{C} / \mathrm{T}$ treatment, and plot in $\mathrm{C} / \mathrm{T}$ treatments) on the NR and D proportions. For all anal- yses, the null hypothesis (similar proportions) was rejected and the observed differences were considered as either significant for $P \leq 0.05$ or highly significant for $P \leq 0.01$. The tests were performed using S-plus 6 Statistical Software (Insightful Corporation, Seattle, WA).

\section{Co-Amplification of narG and napA Fragment}

Genes. Genomic DNA of all nitrate-dissimilating strains for three sampling dates (June 2000, July 2001, and December 2001) was extracted using Wizard Genomic DNA Purification kit (Promega, Madison, WI) according to the manufacturer instructions, except that cell pellets were washed with $0.1 \mathrm{M} \mathrm{NaOH}$ prior to lysis in order to remove exopolysaccharides. narG (the gene encoding the large subunit of membrane-bound nitrate reductase NAR) and napA (gene encoding the large subunit of periplasmic nitrate reductase NAP) fragments were detected using a multiplex PCR protocol. For narG, DMHPF and DNDWI primers (Table 1) were used to amplify a 1008-bp fragment, according to Delorme (Delorme, S $2001 \mathrm{PhD}$ Thesis, Université de Bourgogne, France). Fnap and Rnap primers (Table 1) were used to amplify an 890-bp fragment of napA. They corresponded to previously described V66 and V17 primers [18], which were slightly shortened in order to get annealing temperatures compatible with those of narG primers. The primer sets were designed for the amplification of nar $G$ from Pseudomonas and of napA for a large range of bacteria. Each DNA extract was tested with the multiplex PCR protocol including both primer sets. The PCR mix contained (final concentrations) $1 \times$ Thermophilic DNA Buffer, $3 \mathrm{mM} \mathrm{MgCl}_{2}, 0.2 \mathrm{mM}$ each dNTPs (Promega), $0.25 \mu \mathrm{M}$ each primers DMHPF, DNDWI, Fnap, and Rnap (MWG Biotech, AG, Ebersberg, Switzerland), 0.1 $\mu \mathrm{g} \mu \mathrm{L}^{-1} \mathrm{~T} 4$ Gene 32 Protein (QBiogene), $0.05 \mathrm{U} \mu \mathrm{L}^{-1}$ Taq DNA Polymerase (Promega), and $0.1 \mu \mathrm{L}^{-1}$ pure or 10-fold diluted DNA extract. The reactions were performed in a PTC-200 Peltier Thermal Cycler (MJ Research Inc., MA). This mix was submitted to an initial denaturation step at $95^{\circ} \mathrm{C}$ for $3 \mathrm{~min}, 30$ cycles including $60 \mathrm{~s}$ denaturation at $94^{\circ} \mathrm{C}, 45 \mathrm{~s}$ annealing at $50^{\circ} \mathrm{C}$, and $60 \mathrm{~s}$ elongation at $74^{\circ} \mathrm{C}$, with a final extension step at $74^{\circ} \mathrm{C}$ for $5 \mathrm{~min}$. PCR products were run on $1 \%$ standard agarose (Eurobio, Les Uls, France) gel electrophoresis to check their number and size(s). For each strain, the presence of narG and/or napA fragment(s) was recorded. When both PCR fragments were detected, or when PCR amplicons with an unexpected size were obtained, the DNA extract was resubmitted to PCR amplification with nar $G$ and napA primer sets separately.

RFLP Analysis of narG and napA Fragment Genes. Each PCR product $(\sim 100 \mathrm{ng})$ was submitted to enzymatic restriction with AluI for narG [44] and with HaeIII for napA fragments (HaeIII was selected after 
Table 1. PCR primers used for the amplification of narG and napA gene fragments

\begin{tabular}{lccc}
\hline Primers & Target genes & ${\text { Position } 5^{\prime}-3^{\prime \mathrm{a}}}^{\mathbf{s}^{\prime}-3^{\prime} \text { sequences }^{\mathrm{b}}}$ \\
\hline DMHPF $^{\mathrm{c}}$ & narG & $2413-2426$ & GAYATGCAYCCGTT \\
DNDWI $^{\mathrm{c}}$ & narG & $3412-3425$ & AYCCARTCRTTRTC \\
Fnap $^{\mathrm{d}}$ & napA & $245-269$ & TTYYTNHSNAARATHATGTAYGG \\
Rnap $^{\mathrm{d}}$ & napA & $1102-1123$ & TGYTGRTTRAANCCCATNGTCCA \\
\hline
\end{tabular}

${ }^{\mathrm{a}}$ Position on Pseudomonas aeruginosa strain A01 narG (accession number AE004804) and napA (NC_002516) genes, respectively.

${ }^{\mathrm{b}}$ Ambiguity code: $\mathrm{N}=\mathrm{G}, \mathrm{A}, \mathrm{T}$, or $\mathrm{C} ; \mathrm{Y}=\mathrm{C}$ or $\mathrm{T} ; \mathrm{R}=\mathrm{G}$ or A; $\mathrm{H}=\mathrm{A}, \mathrm{C}$, or $\mathrm{T} ; \mathrm{S}=\mathrm{G}$ or $\mathrm{C}$.

'Delorme, S (2001) PhD Thesis, Université de Bourgogne, France.

${ }^{\mathrm{d}}$ Adapted from [18].

computer simulated restriction analysis of some available napA sequences), according to the enzyme manufacturer's (Promega) instructions. Digestion products were analyzed after electrophoresis in 2\% STG agarose gel (Eurobio) for $2 \mathrm{~h}$ at $3 \mathrm{~V} \mathrm{~cm}^{-1}$. The gels were stained with ethidium bromide and photographed under UV light. The strains displaying a similar restriction profile were clustered in narG and napA operational taxonomic units (OTUs) noted nar1 to nar37 and nap1 to nap49, respectively.

\section{Results and Discussion}

The proportions of nitrate-reducing Pseudomonas as well as the frequency and diversity of membrane-bound (narG) and periplasmic (napA) nitrate reductase genes were investigated for a large collection of Pseudomonas strains isolated at different sampling dates from the root (RE), rhizosphere (RS), and surrounding soil (NRS) of two perennial grasses: the nitrogen-demanding L. perenne and the oligonitrophilic M. coerulea, for plants grown under ambient and elevated $\mathrm{pCO}_{2}$.

Nitrate-Reducing and Denitrifying Activities in mS1-Isolated Pseudomonas. A total of 960 and 286 strains isolated from the root (RE) and associated soil (RS, NRS) of $L$. perenne and $M$. coerulea respectively were typified as
Pseudomonas and retained for further analyses. These 1246 Pseudomonas strains were classified as nitrate reducers (NR), putative denitrifiers (D), or non dissimilators (NDi). For L. perenne, about $52 \%$ of the 960 Pseudomonas strains were able to reduce nitrate to nitrite (501 NR and D strains), including 14\% up to gaseous compounds (135 D strains). For M. coerulea, these proportions were $32 \%$ (94 NR and D strains) and 13\% (38 D strains), respectively.

For L. perenne, logistic regression analysis showed that NR frequencies were sometimes statistically different between the different sampling dates and the replicate plots in $\mathrm{C}$ and $\mathrm{T}$ treatments (especially for plot number 3 under ambient $\mathrm{pCO}_{2}$ ). Interestingly, this plot was described as having lower nutrient availability and received increased fertilization amounts [14]. Differences in NR and $\mathrm{D}$ according to the sampling dates could result from the evolution of the microbiota in relationship to soil water content before the time of sampling. Indeed, soil water content controls air diffusion, which in turn, along with aerobic respiratory activity, determines the soil oxygen content $[17,53,54]$. Low water content may also limit denitrification process because of higher redox potential and nitrate diffusion [51, 54].

Proportions of nitrate-reducing and denitrifying Pseudomonas were compared between NRS, RS and RE
A

\section{L. perenne}

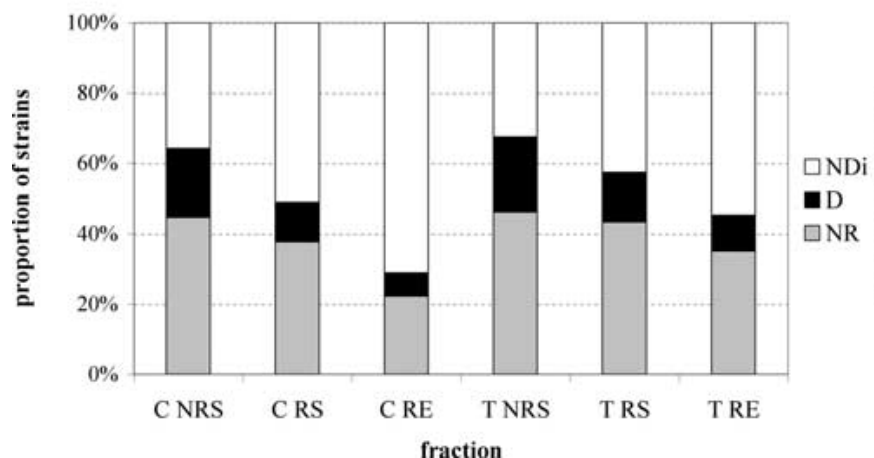

B

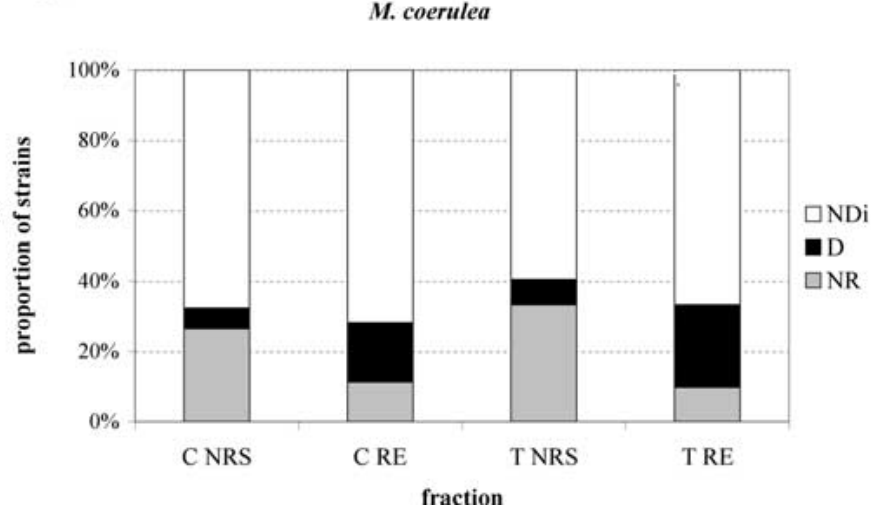

Figure 1. Proportions of nitrate-reducing (NR), denitrifying (D), and non-dissimilating (NDi) Pseudomonas associated with (A) Lolium perenne ( $n=960$ strains) and (B) Molinia coerulea $\left(n=286\right.$ strains): total for all sampling dates. C: Control plots $\left(\operatorname{ambient} \mathrm{pCO}_{2}\right)$; T: $\mathrm{pCO}_{2}$-treated plots; NRS: non-rhizospheric soil; RS: rhizospheric soil; RE: root fraction. 
Table 2. Proportions of nitrate-reducing (NR) and denitrifying (D) Pseudomonas associated with Lolium perenne (total: 960 Pseudomonas strains) and Molinia coerulea (total: 286 Pseudomonas strains)

\begin{tabular}{|c|c|c|c|c|c|c|}
\hline \multirow[b]{2}{*}{ L. perenne } & \multicolumn{3}{|c|}{ Control plots } & \multicolumn{3}{|c|}{ Treated plots } \\
\hline & $N R S$ & $R S$ & $R E$ & $N R S$ & $R S$ & $R E$ \\
\hline June 2000 & $n=49$ & $n=35$ & $n=37$ & $n=57$ & $n=48$ & $n=37$ \\
\hline NR (\%) & $55^{\mathrm{a}}$ & 51 & $24^{\mathrm{bA}}$ & $47^{\mathrm{a}}$ & $73^{\mathrm{b}}$ & $59^{\mathrm{B}}$ \\
\hline D (\%) & 8 & 3 & 0 & 21 & 13 & 3 \\
\hline July 2000 & $n=35$ & $n=23$ & $n=28$ & $n=22$ & $n=18$ & $n=22$ \\
\hline NR (\%) & 37 & 56.5 & 11 & 68 & 50 & 14 \\
\hline $\mathrm{D}(\%)$ & $46^{\mathrm{aA}}$ & 26 & $7^{\mathrm{b}}$ & $18^{\mathrm{B}}$ & 6 & 0 \\
\hline Oct 2000 & $n=32$ & $n=19$ & $n=25$ & $n=24$ & $n=20$ & $n=18$ \\
\hline NR (\%) & 41 & 26 & 12 & 29 & 30 & 6 \\
\hline D (\%) & 9 & 5 & 12 & 29 & 5 & 22 \\
\hline July 2001 & $n=34$ & $n=29$ & $n=34$ & $n=27$ & $n=22$ & $n=13$ \\
\hline NR (\%) & 44 & 17 & 41 & 48 & 18 & 31 \\
\hline D (\%) & 12 & 17 & 6 & 15 & 14 & 8 \\
\hline Dec 2001 & $n=43$ & $n=45$ & $n=45$ & $n=45$ & $n=36$ & $n=38$ \\
\hline NR (\%) & 40 & 36 & $18^{\mathrm{A}}$ & 42 & 22 & $39^{\mathrm{B}}$ \\
\hline \multirow[t]{2}{*}{ D (\%) } & 23 & 9 & 9 & 22 & 25 & 18 \\
\hline & & \multicolumn{2}{|c|}{ Control plot } & & \multicolumn{2}{|c|}{ Treated plot } \\
\hline M. ceorulea & & $N R S$ & $R E$ & & $N R S$ & $R E$ \\
\hline June 2000 & & $n=10$ & $n=17$ & & $n=17$ & $n=18$ \\
\hline NR (\%) & & 0 & 0 & & 29 & 0 \\
\hline D (\%) & & 10 & 0 & & 12 & 0 \\
\hline July 2001 & & $n=14$ & $n=11$ & & $n=14$ & $n=17$ \\
\hline NR (\%) & & 57 & 27 & & $43^{\mathrm{a}}$ & $6^{\mathrm{b}}$ \\
\hline $\mathrm{D}(\%)$ & & 0 & 0 & & 7 & 6 \\
\hline Dec 2001 & & $n=44$ & $n=44$ & & $n=43$ & $n=37$ \\
\hline NR (\%) & & 23 & 11 & & 28 & 16 \\
\hline $\mathrm{D}(\%)$ & & $7^{\mathrm{a}}$ & $27^{\mathrm{b}}$ & & $5^{\mathrm{a}}$ & $43^{\mathrm{b}}$ \\
\hline
\end{tabular}

$n$ : number of strains tested for the corresponding fraction. Different letters indicate NR or D proportions that are statistically different: ${ }^{\mathrm{a}, \mathrm{b}}$ for differences between fractions NRS/RS/RE for a given treatment, and ${ }^{\mathrm{A}, \mathrm{B}}$ for differences between control $(\mathrm{C})$ and elevated $\mathrm{pCO}_{2}$-treated $(\mathrm{T})$ plots for a given fraction. Similar proportions were not indicated. For L. perenne, the proportions were calculated using the three replicate plots.

fractions and between control and elevated $\mathrm{pCO}_{2}$. The results are presented in Table 2 (each sampling date separately) and Fig. 1 (gathering of all sampling dates). Lower frequencies of NR Pseudomonas were generally detected in the root fraction (RE) compared to soil (NRS) fraction, for both plants (Fig. 1), with statistically significant differences for some sampling dates (Table 2). For rhizospheric soil (RS), intermediate NR frequencies were generally observed. The proportions of D strains also decreased in RE compared to NRS fraction for $L$. perenne. However, putative denitrifying Pseudomonas were more frequently detected in root fraction for $M$. coerulea, especially in December 2001.

In the plant-soil systems studied, being for L. perenne cultivated with low $\mathrm{N}$ supply [14], or for M. coerulea growing on its native oligotrophic soil [25], the nitrogen availability is clearly limiting. The availability of $\mathrm{N}$ is dependant on the $\mathrm{N}$ supply (fertilization), $\mathrm{N}$ uptake by the plants, and the $\mathrm{N}$ transformations, which can imply $\mathrm{N}$ losses from the system (i.e., denitrification, leaching). A low availability of nitrate could explain the lower proportions of nitrate-dissimilating strains in root-associ- ated fractions, where $\mathrm{N}$ depletion is increased by plant uptakes. Corre and co-workers [13] suggested a high competition for available $\mathrm{N}$ between microorganisms and plant. Moreover, Nijburg and co-workers [37, 38] noticed that addition of nitrate in the rhizosphere of $G$. maxima resulted in an increased number of NR strains. In order to test the role of nitrate availability, a similar experiment was conducted on $L$. perenne grown with low and high (non-limitative) nitrogen supply, during which the role of nitrate availability was confirmed (L. RousselDelif, S. Tarnawski, J. Hamelin, E.M. Baggs, M. Aragno, and N. Fromin, in preparation).

Nitrate-Dissimilating Pseudomonas Frequency under Elevated $\mathrm{pCO}_{2}$ Treatment. With respect to the effect of $\mathrm{pCO}_{2}$ treatment, higher proportions of nitratereducing and putative denitrifying Pseudomonas were generally observed in the rhizosphere of $L$. perenne grown in $\mathrm{pCO}_{2}$-treated plots compared to control plots (Fig. 1). For $M$. coerulea, no relation between $\mathrm{pCO}_{2}$ treatment and proportions of nitrate dissimilating Pseudomonas was observed. 
Under elevated $\mathrm{pCO}_{2}$, the rhizodeposition rate increases due to higher net photosynthesis rate [15]. This possibly enhances microbial activities that are dependent on C supply, such as nitrogen transformations [57]. Indeed, higher $\mathrm{N}_{2} \mathrm{O}$ emissions were measured in high $\mathrm{N}$ fertilized $L$. perenne monoculture under elevated $\mathrm{pCO}_{2}$ $[1,28]$. Anyway, long-term $\mathrm{CO}_{2}$ enrichment experiments have shown that $\mathrm{N}$ may become a limiting factor for the reaction of plants (including grasses) to elevated $\mathrm{pCO}_{2}$ $[14,58]$. In the studied ( $\mathrm{N}$-limited) plots, experimental results suggested that $\mathrm{pCO}_{2}$ treatment had no significant effect on apparent $\mathrm{N}$ uptake and transformations [22, 48]. Anyway, the nitrate dissimilating Pseudomonas, which were more frequent under elevated $\mathrm{pCO}_{2}$, seemed to benefit from the higher $\mathrm{C}$ entry in the system.

Type of Nitrate Reductase Genes (narG vs napA) among Nitrate-Dissimilating Pseudomonas. The presence of NAR, NAP, or both forms of nitrate reductases was checked by a narG-napA multiplex PCR protocol for the nitrate reducing and denitrifying Pseudomonas strains isolated from three sampling dates. The amplification with crossed pairs of primers for strains harboring both genes did generate additional minor, faint nonspecific PCR products (Fig. 2), which did not interfere with the further restriction analysis. A total of $344 \mathrm{NR}$ or D Pseudomonas isolated from L. perenne and 95 from $M$. coerulea were analyzed (Fig. 3). There was a good correspondence between the nitrate reductase activity and the presence of $n a r G$ and/or napA, as $91.6 \%$ of the 439 NR or D strains generated a narG and/or napA amplification product of expected size. Nine strains yielded a nonspecific amplification product. For the remaining 38 strains (neither narG nor napA detected), the nitrate reductase activity could be related either to a nitrate reductase encoded by narG or napA genes that could not

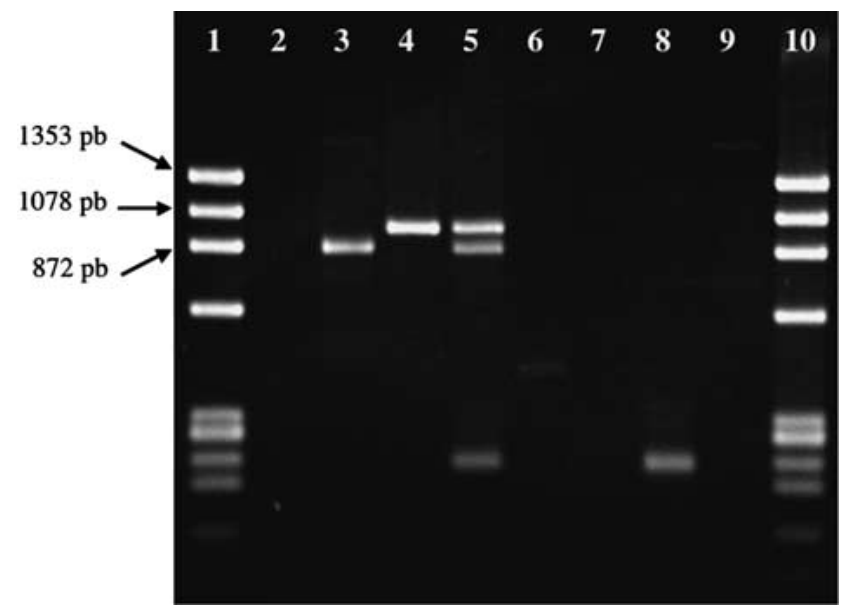

Figure 2. PCR co-amplification of narG and napA gene fragments from strain ELC3RE3. Lanes 1 and 10: $\phi X 174$ DNA/HaeIII molecular weight marker (Promega); lane 2: no DNA template; lane 3: Fnap and Rnap; lane 4: DMHPF and DNDWI; lane 5: Fnap, Rnap, DMHPF, and DNDWI; lane 6: Fnap and DMHPF; lane 7: Fnap and DNDWI; lane 8: Rnap and DMHPF; lane 9: Rnap and DNDWI.

be amplified (quality of the DNA extract, sequence mismatch) or to another form of nitrate reductase.

The NAP as well as the NAR forms were detected in nitrate-dissimilating Pseudomonas strains, as previously suggested [3]. A total of 180 strains (56\%) had the narG gene only, 154 strains (51\%) had the napA gene, and 68 strains $(15.5 \%)$ possessed both nitrate reductase genes. Strains displaying amplification for both genes were more frequently recovered from $M$. coerulea (30.5\% of strains) than from $L$ perenne (11.3\%). Carter et al. [7] noticed that soil isolates displaying a periplasmic nitrate reductase (NAP) were as abundant as those displaying the membrane-bound (NAR) form. A significant proportion
A

\section{L. perenne}

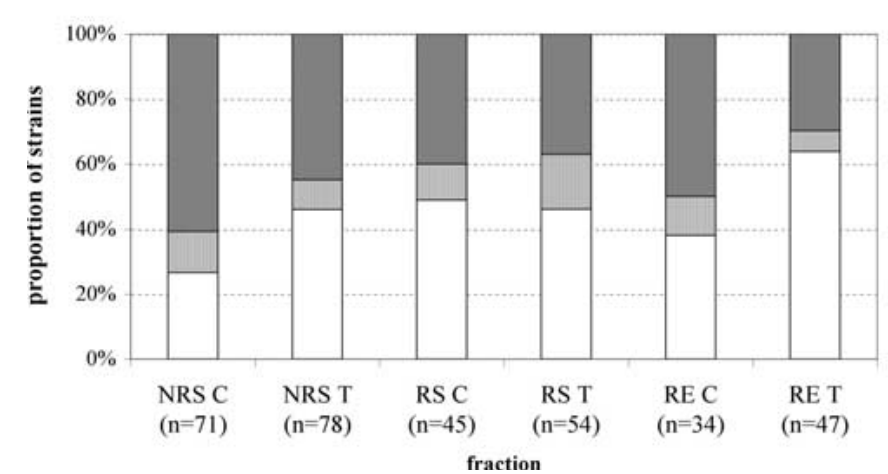

B

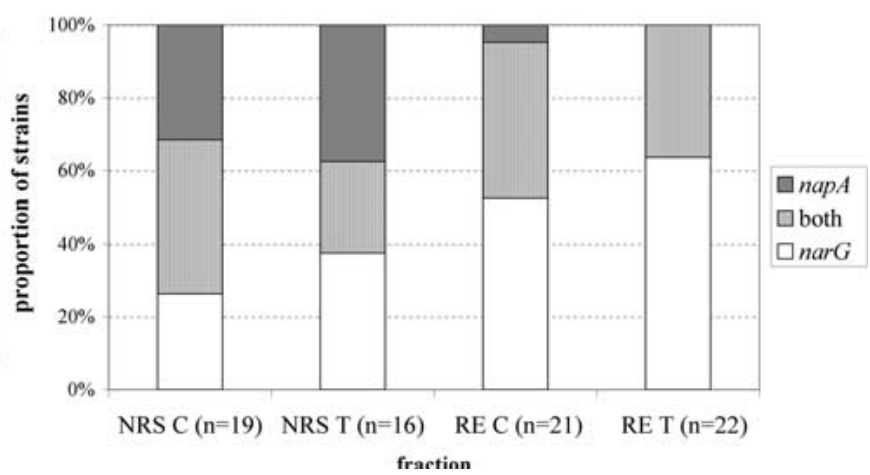

Figure 3. Proportions of strains having narG and/or napA genes among NR Pseudomonas associated with (A) Lolium perenne and (B) Molinia coerulea. NRS: Non-rhizospheric soil; RS: rhizosphere fraction; RE: root fraction; C: control plots; $\mathrm{T}$ : $\mathrm{pCO}_{2}$-treated plots; $n$ : number of strains analyzed (NR strains giving no amplification product or a product with unexpected size were not considered). 
of bacterial isolates displaying both forms was also observed from a freshwater sediment [24].

Most of the putative denitrifying (gas producers) Pseudomonas had the NAR form, alone or together with NAP (65 among the $69 \mathrm{D}$ strains analyzed for $L$. perenne and 27 among the $29 \mathrm{D}$ strains for M. coerulea). A few D strains had only the NAP form (four for L. perenne and two for M. coerulea). In several D strains, including those having the NAP form only, the denitrifying trait was confirmed by the amplification of nos $Z$ gene (encoding the nitrous oxide reductase) fragment (data not shown).

For L. perenne a higher proportion of narG (alone or together with napA) was observed in root compared to soil fraction, for both control (LC) and treated (LT) plots, for the three sampling dates (statistically significant when grouping the data from the three sampling dates). An increasing occurrence of narG form (alone or together with napA) was also detected under elevated $\mathrm{pCO}_{2}$ treatment as compared to control plots, for both NRS and RE fractions (Fig. 3). Such an increase was observed at the three sampling dates for root fraction, and in June 2000 and December 2001 for soil fraction (data not shown). Regarding this distribution of nitrate reductase forms, the Pseudomonas isolated from RS fraction were intermediate and the effects of $\mathrm{pCO}_{2}$ treatment was less straightforward. For M. coerulea, higher proportions of nitrate-reducing Pseudomonas strains having narG (alone or together with napA) were also noticed in root compared to soil fraction and under elevated $\mathrm{pCO}_{2}$ content for both root and soil fraction (Fig. 3).

These results taken as a whole suggest that the NAR and NAP forms probably have different functions within the corresponding organisms, despite the fact that they catalyze a similar reaction. The periplasmic nitrate reductase (NAP) is probably a functionally versatile enzyme according to the organisms [42, 47]. In some organisms, NAP clearly has a role in anaerobic denitrification $[3,47,50]$. For some others, it may provide the biochemical apparatus for aerobic nitrate respiration [7, 35], including for Pseudomonas strains [18]. As noted by some authors $[9,20]$, nitrate-reducing bacteria were abundant in soil $(66 \%$ of the 368 Pseudomonas in soil fraction for L. perenne), a prevailing oxic environment, except in case of poorly drained soils. An aerobic nitrate respiration would be useful on organic carbon substrates or under micro-oxic conditions [4], such conditions being frequent in soil and rhizosphere microhabitats. In that sense, Carter et al. [7] suggested that the ability to corespire oxygen and nitrate may be particularly important in environments that are rich in organic carbon or subjected to limiting or fluctuating oxygen availability, such as in soil aggregates [40]. The membrane-bound nitrate reductase (NAR) is expressed under low oxygen partial pressure $[2,43]$. A predominance of this form was observed among Pseudomonas isolated from root environment, where oxygen content is low. We also provided evidence of a higher proportion of NAR form among Pseudomonas strains isolated from plants grown under elevated $\mathrm{pCO}_{2}$. The significance of this result is unclear. However, a predominance of the NAR form was expected under elevated $\mathrm{pCO}_{2}$, where higher amounts of free sugars are released in the rhizosphere, leading to increased oxygen consumption by microbial cell respiration (G. Bachmann, T. Röhrich, K. Fertinger, and F. Thomas, pers. comm.).

Diversity of narG and napA Genes. The diversity of narG and napA genes among nitrate-reducing and putative denitrifying Pseudomonas was then evaluated by restriction analysis of PCR products. A total of 287 strains generated an interpretable restriction profile. Both genes displayed a high level of diversity: the 188 narGharboring strains were clustered into 37 narG (noted nar1 to nar37) and the 205 nap $A$-harboring strains in 49 napA (noted nap1 to nap49) OTUs. The most abundant narG and napA OTUs were identified among strains isolated at several sampling dates (data not shown), confirming the good reproducibility of the results over time.

Forty-three Pseudomonas strains harboring both nar $G$ and napA genes generated usable restriction profiles for both genes. The strains fell in 11 narG OTUs and 26 napA OTUs, and no relationship between the type of narG and that of napA could be demonstrated. As mentioned above, most of the putative denitrifying strains harbored the narG gene. They were clustered into 14 of the 37 narG OTUs, including the three most abundant OTUs. For instance, $77 \%$ of the strains belonging to the most abundant narG OTU were putative denitrifiers. The 35 denitrifying strains harboring the napA gene (alone or together with narG) were distributed among 19 of the 49 napA OTUs. In both cases, none of the major narG or napA OTUs was composed only of D strains or of NR strains.

For L. perenne, the allocation of strains into the different OTUs was considered according to the root proximity and the $\mathrm{pCO}_{2}$ (Fig. 4). The 141 narG strains grouped into 31 narG OTUs (noted nar1 to nar31). Twelve narG OTUs were represented by a single isolate. The 167 napAharboring strains were clustered into 38 different napA OTUs, noted nap1 to nap38, of which 17 were represented by a single strain. The most abundant narG (nar1 to nar5) and napA (nap1 to nap5) OTUs as well as many others were recovered from soil and root-associated fractions, and from both control and $\mathrm{pCO}_{2}$-treated plots. Interestingly, nap4 was quite abundant among rhizosphere strains, whereas it was poorly represented in other fractions, and two napA OTUs (nap9 and nap13) were detected among root strains for control plots only.

Several narG (nar1, nar2, nar3, nar11, and nar19) and napA OTUs (nap5, nap11, nap22, and nap23) were 
A

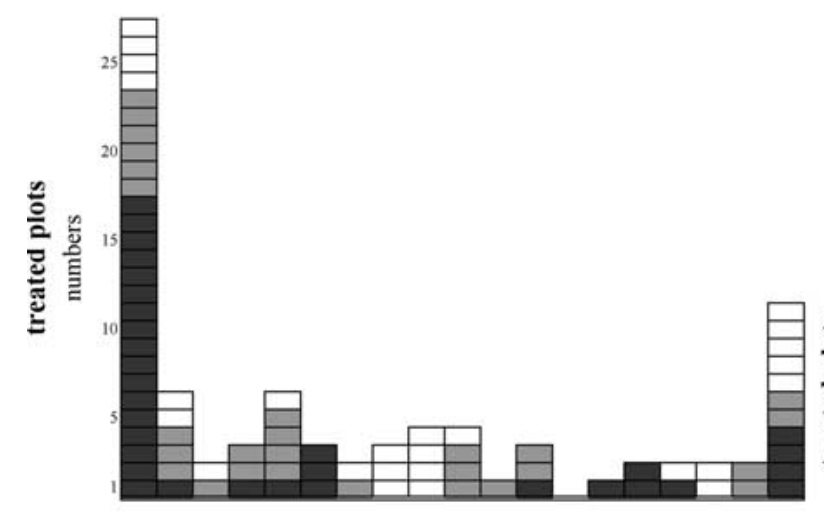

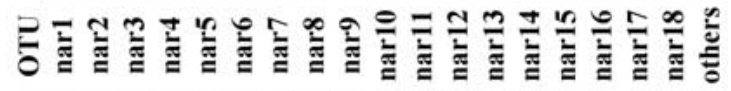
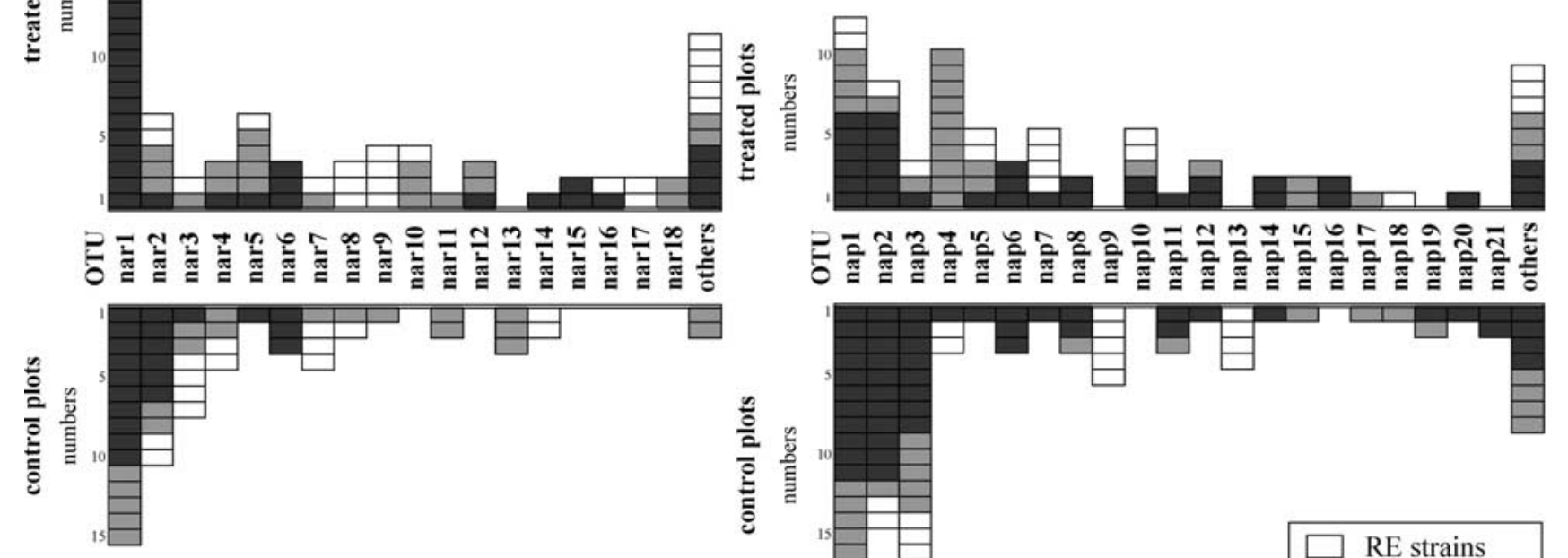

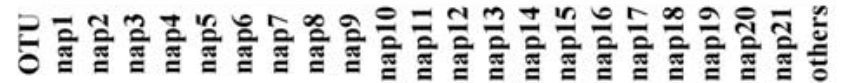

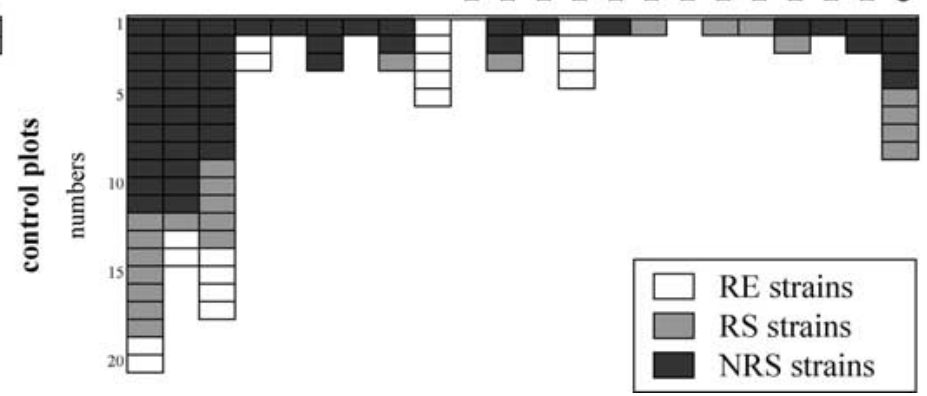

Figure 4. Distribution of nitrate-dissimilating Pseudomonas strains among narG (A) and napA (B) OTUs for Lolium perenne. Each box represents a strain. OTUs harboring a single strain $(n=1)$ were grouped as "others".

detected associated with both plants (data not shown). OTUs nar1, nar2, and nar3 were detected as the most abundant OTUs for L. perenne as well as for M. coerulea: they represented 34 of the 47 strains isolated from $M$. coerulea. However, six additional narG OTUs (with $n \geq$ 2 ) were detected among strains from $M$. coerulea only.

These data suggest that root proximity and $\mathrm{pCO}_{2}$ treatment had no major influence on the diversity of these genes, and consequently of the corresponding organisms. A study dealing with the diversity of narG sequences (Kathrin Deiglmayr, unpublished data) reached similar conclusions (no relation between $\mathrm{pCO}_{2}$ treatment and the structure of the total nitrate-reducing community for L. perenne grown in the FACE, but a different structure within the replicate plots). Moreover, growth of perennial grasses at the same location for several years may lead to the enrichment of the most adapted bacterial populations in both fractions. This was previously observed for dinitrogen-fixing bacteria using a molecular inventory of nifH sequences in a natural meadow [25].

In conclusion, the bacteria belonging to the genus Pseudomonas were shown to be responsive to the "rhizosphere effect" as well as to elevated $\mathrm{pCO}_{2}$, as their abundance increased with root proximity, and in the rhizosphere of $L$. perenne grown under elevated $\mathrm{pCO}_{2}$
[33]. As shown in the present study, the Pseudomonas responded to these factors also in terms of population structure (proportions of nitrate-dissimilating strains as well as the type of nitrate reductase), even if no effect on the diversity of the corresponding genes was observed. Some authors suggested that shifts in the structure of denitrifying bacteria in soil could influence the in situ denitrification rate $[8,27]$. Moreover, the nitrate-dissimilating Pseudomonas guilds associated with L. perenne and $M$. coerulea responded in a similar way to the plant and to the $\mathrm{pCO}_{2}$ treatment, despite the different ability of these plants to use soil nitrogen [55]. Such a response may affect the in situ nitrate dissimilation activity, with probable consequences for the nitrogen transformations and budget of these soils.

\section{Acknowledgments}

This work was supported by the Swiss National Science Foundation (grant numbers 3100-055899.98 and 31-68208.02). We are also grateful to the Swiss $\mathrm{Na}$ tional Centre of Competence in Research (NCCR) "Plant Survival." We thank Marie-Laure Heusler for technical assistance, Jakob Zopfi and Raymond Flynn for English corrections, and Jacqueline Moret for statistical analysis. 


\section{References}

1. Baggs, EM, Richter, M, Cadisch, G, Hartwig, UA (2003) Denitrification in grass swards is increased under elevated atmospheric $\mathrm{CO}_{2}$. Soil Biol Biochem 35: 729-732

2. Baumann, B, Snozzi, M, Zehnder, JB, van der Meer, JR (1996) Dynamics of denitrification activity in Paracoccus denitrificans in continuous culture during aerobic-anaerobic changes. J Bacteriol 178: 4367-4374

3. Bedzyk, L, Wang, T, Ye, RW (1999) The periplasmic nitrate reductase in Pseudomonas sp. strain G-179 catalyzes the first step of denitrification. J Bacteriol 181: 2802-2806

4. Berks, BC, Ferguson, SJ, Moir, JWB, Richardson, DJ (1995) Enzymes and associated electron transport that catalyse the respiratory reduction of nitrogen oxides and oxyanions. Biochim Biophys Acta 1232: $97-173$

5. Braun-Howland, EB, Vescio, PA, Nierzwicki-Bauer, SA (1993) Use of a simplified cell blot technique and 16S rRNA-directed probes for identification of common environmental isolates. Appl Environ Microbiol 159: 3219-3224

6. Carnol, M, Hogenboom, L, Ewajach, M, Remacle, J, Ceulemans, R (2002) Elevated atmospheric $\mathrm{CO}_{2}$ in open top chambers increases net nitrification and potential denitrification. Global Change Biol 8: $590-598$

7. Carter, JP, Hsaio, YH, Spiro, S, Richardson, DJ (1995) Soil and sediment bacteria capable of aerobic nitrate respiration. Appl Environ Microbiol 61: 2852-2858

8. Cavigelli, MA, Robertson, GP (2001) Role of denitrifier diversity in rate of nitrous oxide consumption in a terrestrial ecosystem. Soil Biol Biochem 33: 297-310

9. Chèneby, D, Philippot, L, Hartmann, A, Henault, C, Germon, JC (2000) 16S rDNA analysis for characterization of denitrifying bacteria isolated from three agricultural soils. FEMS Microbiol Ecol 34: 121-128

10. Chèneby, D, Hallet, S, Mondon, A, Martin-Laurent, F, Germon, JC, Philippot, L (2003) Genetic characterization of the nitrate reducing community based on nar $G$ nucleotide sequence analysis. Microb Ecol 46: 113-121

11. Clays-Josserand, A, Lemanceau, P, Philippot, L, Lensi, R (1995) Influence of two plant species (flax and tomato) on nitrogen dissimilative abilities within fluorescent Pseudomonas spp. Appl Environ Microbiol 61: 1745-1749

12. Clays-Josserand, A, Ghiglione, JF, Philippot, L, Lemanceau, P, Lensi, R (1999) Effect of soil type and plant species on the fluorescent pseudomonads nitrate dissimilating community. Plant Soil 209: 275-282

13. Corre, MD, Schnabel, RR, Stout, WL (2002) Spatial and seasonal variation of gross nitrogen transformations and microbial biomass in a Northeastern US grassland. Soil Biol Biochem 34: 445-457

14. Daepp, M, Suter, D, Almeida, JPF, Isopp, H, Hartwig, UA, Frehner, M, Blum, H, Nösberger, J, Lüscher, A (2000) Yield response of Lolium perenne swards to free air $\mathrm{CO}_{2}$ enrichment increased over six years in a high $\mathrm{N}$ input system on fertile soil. Global Change Biol 6: 805-816

15. Darrah, PR (1996) Rhizodeposition under ambient and elevated $\mathrm{CO}_{2}$ levels. Plant Soil 187: 265-276

16. Delorme, S, Philippot, L, Edel-Hermann, V, Deulvot, C, Mougel, C, Lemanceau, P (2003) Comparative genetic diversity of the narG, $n o s Z$, and $16 \mathrm{~S}$ rRNA genes in fluorescent pseudomonads. Appl Environ Microbiol 69: 1004-1012

17. Drury, CF, McKenney, DJ, Findlay, WI (1991) Relationships between denitrification, microbial biomass and indigenous soil properties. Soil Biol Biochem 23: 751-755

18. Flanagan, DA, Gregory, LG, Carter, JP, Karakas-Sen, A, Richardson, DJ, Spiro, S (1999) Detection of genes for periplasmic nitrate reductase in nitrate respiring bacteria and in community DNA. FEMS Microbiol Lett 177: 263-270

19. Fromin, N, Achouak, W, Thiéry, JM, Heulin, T (2001) The genotypic diversity of Pseudomonas brassicacearum populations isolated from roots of Arabidopsis thaliana: influence of plant genotype. FEMS Microbiol Ecol 37: 21-29

20. Gamble, TN, Betlach, MR, Tiedje, JM (1977) Numerically dominant denitrifying bacteria from world soils. Appl Environ Microbiol 33: 916-939

21. Ghiglione, JF, Gourbière, F, Potier, P, Philippot, L, Lensi, R (2000) Role of respiratory nitrate reductase in ability of Pseudomonas fluorescens YT101 to colonize the rhizosphere of maize. Appl Environ Microbiol 66: 4012-4016

22. Gloser, V, Jezikovń, M, Lüscher, A, Frehner, M, Blum, H, Nösberger, J, Hartwig, UA (2000) Soil mineral nitrogen availability was unaffected by elevated atmospheric $\mathrm{pCO}_{2}$ in a four year old field experiment (Swiss FACE). Plant Soil 227: 291-299

23. Gregory, LG, Karakas-Sen, A, Richardson, DJ, Spiro, S (2000) Detection of genes for membrane-bound nitrate reductase in nitrate-respiring bacteria and in community DNA. FEMS Microbiol Lett 183: 275-279

24. Gregory, LG, Bond, PL, Richardson, DJ, Spiro, S (2003) Characterization of nitrate-respiring bacterial community using the nitrate reductase gene (narG) as a functional marker. Microbiology 149: 229-237

25. Hamelin, J, Fromin, N, Teyssier-Cuvelle, S, Tarnawski, S, Aragno, M (2002) nifH gene diversity in the bacterial community associated with the rhizosphere of Molinia coerulea, an oligonitrophilic perennial grass. Environ Microbiol 4: 477-481

26. Hebeisen, T, Lüscher, V, Zanetti, S, Fischer, BU, Hartwig, UA, Frehner, M, Hendrey, GR, Blum, H, Nösberger, J (1997) Growth response of Trifolium repens and Lolium perenne as monocultures and bi-species mixture to free air $\mathrm{CO}_{2}$ enrichment and management. Global Change Biol 3: 149-160

27. Holtan-Hartwig, L, Dörsch, P, Bakken, LR (2000) Comparison of denitrifying communities in organic soil: kinetics of $\mathrm{NO}_{3}^{-}$and $\mathrm{N}_{2} \mathrm{O}$ reduction. Soil Biol Biochem 32: 833-843

28. Ineson, $\mathrm{P}$, Coward, PA, Hartwig, UA (1998) Soil gas fluxes of $\mathrm{N}_{2} \mathrm{O}$, $\mathrm{CH}_{4}$ and $\mathrm{CO}_{2}$ beneath Lolium perenne under elevated $\mathrm{CO}_{2}$ : the Swiss free air carbon dioxide enrichment experiment. Plant Soil 198: 89-95

29. von Linne Berg, KH, Bothe, H (1992) The distribution of denitrifying bacteria in soils monitored by DNA-probing. FEMS Microbiol Ecol 86: 331-340

30. Locatelli, L, Tarnawski, S, Hamelin, J, Rossi, P, Aragno, M, Fromin, N (2002) Specific PCR amplification for the genus Pseudomonas targeting the $3^{\prime}$ half of $16 \mathrm{~S}$ rDNA and the whole 16S-23S rDNA spacer. Syst Appl Microbiol 25: 220227

31. Mahmood, T, Ali, R, Malik, KA, Shamsi, SRA (1997) Denitrification with and without maize plants (Zea mays L) under irrigated field conditions. Biol Fertil Soil 24: 323-328

32. Mahne, I, Tiedje, JM (1995) Criteria and methodology for identifying respiratory denitrifiers. Appl Environ Microbiol 61: 11101115

33. Marilley, L, Hartwig, UA, Aragno, M (1999) Influence of an elevated atmospheric $\mathrm{CO}_{2}$ content on soil and rhizosphere bacterial communities beneath Lolium perenne and Trifolium repens under field conditions. Microb Ecol 38: 39-49

34. Martín-Olmedo, P, Rees, RM, Grace, J (2002) The influence of plants grown under elevated $\mathrm{CO}_{2}$ and $\mathrm{N}$ fertilisation on soil nitrogen dynamics. Global Change Biol 8: 643-657

35. McDevitt, C, Burrell, P, Blackall, LL, McEwan, AG (2000) Aerobic nitrate respiration in a nitrite oxidising bioreactor. FEMS Microbiol Ecol 184: 113-118 
36. Moreno-Vivián, C, Ferguson, SJ (1998) Definition and distinction between assimilatory, dissimilatory and respiratory pathways. Mol Microbiol 29: 664-666

37. Nijburg, JW, Laanbroek, HJ (1997) The influence of Glyceria maxima and nitrate input on the composition and nitrate metabolism of the dissimilatory nitrate-reducing bacterial community. FEMS Microbiol Ecol 22: 57-63

38. Nijburg, JW, Coolen, MJL, Gerards, S, Gunnewiek, PJAK, Laanbroek, HJ (1997) Effects of nitrate availability and the presence of Glyceria maxima on the composition and activity of the dissimilatory nitrate-reducing bacterial community. Appl Environ Microbiol 63: 931-937

39. Nogales, B, Timmis, KN, Nedwell, DB, Osborn, AM (2002) Detection and diversity of expressed denitrification genes in estuarine sediments after reverse transcription-PCR amplification from mRNA. Appl Environ Microbiol 68: 5017-5025

40. Parry, S, Renault, P, Chenu, C, Lensi, R (1999) Denitrification in pasture and cropped soil clods as affected by spore space structure. Soil Biol Biochem 31: 493-501

41. Philippot, L (2002) Denitrifying genes in bacterial and archeal genomes. Biochim Biophys Acta 1577: 355-376

42. Philippot, L, Højberg, O (1999) Dissimilatory nitrate reductases in bacteria. Biochim Biophys Acta 1446: 1-23

43. Philippot, L, Mirleau, P, Mazurier, S, Siblot, S, Hartmann, A, Lemanceau, P, Germon, JC (2001) Characterization and transcriptional analysis of Pseudomonas fluorescens denitrifying clusters containing the nar, nir, nor and nos genes. Biochim Biophys Acta 1517: 436-440

44. Philippot, L, Piutti, S, Martin-Laurent, F, Hallet, S, Germon, JC (2002) Molecular analysis of the nitrate-reducing community from unplanted and maize-planted soil. Appl Environ Microbiol 68: 6121-6128

45. Potter, L, Angove, H, Richardson, D, Cole, J (2001) Nitrate reduction in the periplasm of gram-negative bacteria. Adv Microb Physiol 45: 51-112

46. Prade, K, Trolldenier, G (1990) Denitrification in the rhizosphere of rice and wheat seedlings as influenced by plant $\mathrm{K}$ status, airfilled porosity and substrate organic matter. Soil Biol Biochem 22: 769-773

47. Richardson, DJ, Berks, BC, Russel, DA, Spiro, S, Taylor, CJ (2001) Functional, biochemical and genetic diversity of prokaryotic nitrate reductases. Cell Mol Life Sci 58: 165-178
48. Richter, M, Hartwig, UA, Frossard, E, Nösberger, J, Cadisch, G (2003) Gross fluxes of nitrogen in grassland soil exposed to elevated atmospheric $\mathrm{pCO}_{2}$ for seven years. Soil Biol Biochem 35: $1325-1335$

49. Smart, DR, Ritchie, K, Stark, JM, Bugbee, B (1997) Evidence that elevated $\mathrm{CO}_{2}$ levels can indirectly increase rhizosphere denitrifier activity. Appl Environ Microbiol 63: 4621-4624

50. Stewart, V, Lu, Y, Darwin, AJ (2002) Periplasmic nitrate reductase (NapABC enzyme) supports anaerobic respiration by Escherichia coli K-12. J Bacteriol 184: 1314-1323

51. Strong, DT, Fillery, IRP (2002) Denitrification response to nitrate concentrations in sandy soils. Soil Biol Biochem 34: 945954

52. Tarnawski, S, Hamelin, J, Locatelli, L, Aragno, M, Fromin, N (2003) Examination of Gould's modified S1 (mS1) selective medium and Angle's non-selective medium for collecting diversity of Pseudomonas spp. in soil and root environments. FEMS Microbiol Ecol 45: 97-104

53. Tiedje, JM (1988) Ecology of denitrification and dissimilatory nitrate reduction to ammonium. In: Zehnder, AJB (Ed.) Biology of Anaerobic Bacteria, John Wiley and Sons, New York, pp 179244

54. van Oorschot, M, van Gaalen, N, Maltby, E, Mockler, N, Spink, A, Verhoeven, JTA (2000) Experimental manipulation of water levels in two French riverine grassland soils. Acta Oecol Int J Ecol 21: 4962

55. Vázquez de Aldana, BR, Berendse, F (1997) Nitrogen-use efficiency in six perennial grasses from contrasting habitats. Funct Ecol 11: 619-626

56. Vitousek, PM, Mooney, HA, Lubchenco, J, Melillo, JM (1997) Human domination of Earth's ecosystem. Science 277: 494499

57. Zak, DR, Pregitzer, SKS, King, JS, Holmes, WE (2000) Elevated atmospheric $\mathrm{CO}_{2}$, fine roots and the response of soil microorganisms: a review and hypothesis. New Phytol 147: 201-222

58. Zanetti, S, Hartwig, UA, van Kessel, C, Lüscher, A, Hebeisen, T, Frehner, M, Fisher, BU, Hendrey, GR, Blum, H, Nösberger, J (1997) Does nitrogen nutrition restrict the $\mathrm{CO}_{2}$ response of fertile grassland lacking legumes? Oecologia 112: 17-25

59. Zumft, WG (1997) Cell biology and molecular basis of denitrification. Microbiol Mol Biol Rev 61: 533-616 